Article

\title{
Indigenous Rock Art Tourism in Australia: Contexts, Trajectories, and Multifaceted Realities
}

\author{
Noelene A. Cole ${ }^{1, *}$ and Lynley A. Wallis ${ }^{2}$ (D \\ 1 College of Arts, Society and Education, James Cook University, Smithfield Qld 4878, Australia \\ 2 Nulungu Research Institute, The University of Notre Dame Australia, Broome WA 6725, Australia; \\ lynley.wallis@nd.edu.au \\ * Correspondence: noelene@a-ncole.com
}

Received: 9 September 2019; Accepted: 20 November 2019; Published: 6 December 2019

\begin{abstract}
This paper focuses on Australian Indigenous rock art tourism, a field that has received limited research attention. Our aim is to identify aspects which are invisible in tourism promotions. We note trends in rock art tourism and related research, survey the Australian situation, and employ a case study approach to outline the development of Indigenous rock art tourism in Kakadu National Park (KNP) and parts of the Quinkan (Laura Cooktown) region. In both regions, Aboriginal communities inherited legacies of top down decision-making and bureaucratic methods. Although the Laura people transitioned to a community-based system and a successful ranger program, they face challenges in achieving their aspirations for sustainable rock art tourism. KNP communities, subsumed into an unwieldy joint management arrangement for the World Heritage listed National Park, are faced with competing values and perspectives of the dominant government system. A centerpiece of the Balnggarrawarra tourism initiative is the ranger/tour guide system of the type which operated for some years at Laura and was introduced briefly at KNP. The model incorporates key elements of sustainable Indigenous tourism-traditional owner control and jobs, land care, conservation, cultural preservation, partnerships, and public education. Notwithstanding contemporary challenges and realities, a unifying theme is caring for rock art.
\end{abstract}

Keywords: rock art; Indigenous tourism; Kakadu National Park; Quinkan region

\section{Introduction}

For Australia's Indigenous peoples, rock art retains its ancestral values as a symbol of cultural identity and continuing connections to land (George et al. 1995). This same rock art is promoted by Tourism Australia (Henley 2019) as a "breathtaking" component of "Aboriginal Australia", the latter being "a key point of differentiation in today's highly competitive international tourism market" (Department of Foreign Affairs and Trade 2019).

While there is a vast body of research relating to the wider field of "Indigenous tourism", the niche sector of rock art tourism is virtually unstudied (Deacon 2006, p. 377). Further, although rock art is known to be internationally endangered due to pressures of tourism, commercial development and natural impacts, research into the management of such pressures is often inadequate and out of date (Agnew et al. 2015). There is, however, a growing body of international research into the social contexts of rock art tourism and its relationships to communities. ${ }^{1}$ Similarly, in their global study of rock art tourism, Duval et al. (2018) outlined impacts of rock art tourism upon postcolonial

1 See Fernandes et al. (2008) for Coa, Portugal, Little and Borona (2014), for Kenya, Africa, and Gao (2017) for the Huashan rock art area, China. 
communities in Tanzania. As a result of identifying inequities in the system, Duval et al. (2018) raised searching questions about the conduct of this genre of tourism: for whom and how do rock art sites comprise heritage, and how does the development of rock art sites for tourism take into account their multifaceted heritage reality? In concluding their study, Duval et al. (2018, p. 1037) pose another critical question: "Who does it (rock art tourism) benefit, and how?" For Australian researchers, these vital questions recall Altman (1989, p. 470) unsettling observation that one of the challenges of Australian cultural tourism is that "Aboriginal people [may] ... be poorer with tourism than without".

Clearly there is a need to heed the call by Whitford and Ruhanen (2016, p. 3) for a "more comprehensive understanding of Indigenous tourism from the perspective of Indigenous stakeholders". With this in mind we consider some of the realities of Australian rock art tourism. In particular, we focus on case studies in two significant rock art regions of northern Australia-the Quinkan region of Cape York Peninsula in Queensland (Qld) and Kakadu National Park in the Northern Territory (NT). Although similarly positioned in sandstone provinces where rock art has played a substantial role in the emergence of current land tenure regimes, the regions have had different trajectories of rock art tourism. To provide general context we refer to some international examples and to features of rock art tourism in Australia. Although the latter operates in a post-Native Title environment, it was first developed within an ethos of post-colonial inequity, signs of which still remain, as outlined below. Fundamental to our discussion is the premise that rock art is a unique type of Indigenous cultural heritage which, beyond its mysterious value as "art", functions very specifically as a symbol of cultural identity and confers "rights to a place" (Duval et al. 2018, p. 1035).

\section{Australian Rock Art Tourism in Global Context}

Rock art is a key ingredient of the tourism experience known as "cultural" travel, which typically focuses on culturally differentiated destinations, "history", natural landscapes and opportunities to learn and engage with local and/or Indigenous communities, e.g., see (Abascal et al. 2016; Bonet 2003; Du Cros and McKercher 2015; Galliford 2011; Tonnaer 2010). Although it is oddly missing from a recent expert review of cultural tourism research (Richards 2018) and from the World Tourism Organisation's latest report (World Tourism Organisation 2018), rock art tourism most certainly exists as a niche type of cultural tourism, if on a variable scale. The "prehistoric rock art trails" promoted by the (Council of Europe 2019) as a tourism initiative to link 112 World Heritage (WH) listed sites across northern and western Europe attract 1.5 million visitors a year. Importantly the route is presented as a unifying theme, a "cultural and tourism resource for Europe, as the first major cultural, social and symbolic expression of humankind" (Council of Europe 2019). In China, the WH-listed Magao Caves, a complex of some 400 caves containing Buddhist art, attract hundreds of thousands of visitors each year, with a peak season limit of 19,000 per day (China Daily 2016). India's sole WH listed rock art site, Bhimbetka, receives 85,000 visitors per year (Krishna 2015) compared with eight million at the Taj Mahal (Katz 2018). In South Africa, the tourist profile is so low that Duval and Smith (2013, p. 134) have concluded that "rock art needs tourism to valourise its conservation".

Public visitation to Australian rock art sites is said to have developed in the 1980s as a side effect of increased visitation to national parks such as Kakadu, Flinders Ranges, Carnarvon Gorge, and the Flinders Islands (Dragovich 1993; Gale and Jacobs 1987; Sullivan 1992; Walsh 1991). Visitation at Kakadu in particular may have been boosted by the international success of the movie "Crocodile Dundee" (O’Regan 1988, pp. 172-73; Riley and Van Doren 1992). In the 21st century these parks still tend to attract visitors for their natural values rather than their rock art as identified also in South Africa's uKhahlamba/Drakensburg World Heritage Site (Duval and Smith 2013). Approximate visitor numbers are published for Kakadu and Arnhem Land (199,000 tourists annually, calculated as a three-year average of 2016-2018; (Tourism NT 2018)), and for Nitmiluk National Park (263,500 in 2018; Department of Tourism, Sport and Culture NT 2019). However, as it is possible to visit these parks without seeing rock art, and because rock art encounters may be entirely incidental, it cannot be assumed that these numbers are indicators of rock art tourism. 
Unlike the older national parks mentioned above, the more recently established Western Australian national parks, Murujuga in the Pilbara and Mitchell River in the Kimberley, are defined by their Aboriginal rock art. Although tourism is a key industry, visitation statistics in these remote regions are difficult to quantify (Kimberley Development Commission 2019), and individual park visitor numbers are not published. Likewise, although Cape York Peninsula (hereafter Cape York) is a beacon for tourists interested in four-wheel driving, camping, and fishing, statistics on tourism are sparse. Observations at the Split Rock art site, on the main road near Laura in Quinkan Country suggest that 30-40 people visit daily in the tourist season, and many hundreds visit during the biennial, three-day Laura Dance Festival (Buhrich and the Laura Rangers 2017). Although the Cook Shire Council Economic Profile (2015) recorded a doubling of visitors to Cooktown from c. 13,000 in 2005 to 26,889 in 2013 , visitation levels are obviously much lower than those for Kakadu/Arnhem Land and Nitmiluk.

Table 1 provides an indication of the availability of rock art tourism in Australia. The information was retrieved through a series of internet searches based on localities identified in national maps and overviews of Australia's rock art regions-see (McDonald and Clayton 2016; Morwood 2002; Taçon 2001) —and refers only to advertised public access in national parks, other protected areas and various Aboriginal lands. If advertised access was not identified, for example in northwest Central Queensland, Torres Strait and some other regions referred to by McDonald and Clayton (2016), the relevant areas were not included. The table therefore represents a snapshot for the purposes of this introductory overview, not an exhaustive survey. Many of the listed areas are jointly managed by government agencies and Traditional Owners who permit visits to rock art sites through tours and/or self-guided options. In other Aboriginal lands (see AL in the table), formal visits can be arranged through the landowners. Tours are variously presented by Indigenous or non-Indigenous commercial operations, or by Traditional Owner rangers or community members. In many cases, Traditional Owner communities authorise, oversee, and provide protocols for tours and/or self-guided walks but otherwise do not engage directly in tourism activities. A relatively small number of Aboriginal-owned and operated businesses provide specialized rock art tours at a local or regional level. The data suggests that rock art tourism in Australia, although widely available, is far more modest in scale than it is internationally. It is a sub-set of Indigenous tourism and its locations tend to be remote from Australia's main tourist destinations and population centres on the eastern seaboard.

Table 1. Snapshot of Australian rock art tourism. AL = Aboriginal land; Joint management $=$ area is jointly managed as a national park or reserve by Traditional Owners and government agencies; NHL $=$ National Heritage List; NP = National Park; Tour $=$ advertised tour; $\boldsymbol{V}=$ tour or self-guided walk identified in the area.

\begin{tabular}{|c|c|c|c|c|c|}
\hline State/Territory & Area & Tenure/Status & Joint Management & Tour & Self-Guided Walks \\
\hline $\begin{array}{c}\text { Australian Capital } \\
\text { Territory }\end{array}$ & Namadgi & NP & & $\boldsymbol{v}$ & $\boldsymbol{v}$ \\
\hline \multirow{5}{*}{ New South Wales } & Blue Mountains & $\begin{array}{c}\text { NP } \\
\text { NHL } \\
\text { WH }\end{array}$ & & $\checkmark$ & $\boldsymbol{v}$ \\
\hline & Kur-in-gai Chase & NP & & $\boldsymbol{V}$ & $\boldsymbol{V}$ \\
\hline & Royal National Park & NP & & $\checkmark$ & $\checkmark$ \\
\hline & Mt Grenfell & Historic Site & $\checkmark$ & & $\boldsymbol{V}$ \\
\hline & Mutawintji & NP & $\checkmark$ & $\checkmark$ & $\checkmark$ \\
\hline
\end{tabular}


Table 1. Cont.

\begin{tabular}{|c|c|c|c|c|c|}
\hline State/Territory & Area & Tenure/Status & Joint Management & Tour & Self-Guided Walks \\
\hline \multirow{9}{*}{ Northern Territory } & $\begin{array}{c}\text { Arnhem Land (various } \\
\text { locations including Injalak) }\end{array}$ & AL & & $\boldsymbol{V}$ & \\
\hline & Judbara/Gregory & NP & $\checkmark$ & & $\checkmark$ \\
\hline & $\begin{array}{c}\text { Kakadu: Burrungkuy } \\
\text { (Nourlangie Rock), } \\
\text { Nanguluwurr (Nourlangie } \\
\text { region) and Ubirr } \\
\text { (East Alligator region) }\end{array}$ & $\begin{array}{l}\text { NP } \\
\text { NHL } \\
\text { WH }\end{array}$ & $\boldsymbol{v}$ & $\checkmark$ & $\checkmark$ \\
\hline & $\begin{array}{l}\text { Napwerte/Ewaninga } \\
\text { Rock Carvings }\end{array}$ & Conservation Reserve & $\checkmark$ & $\checkmark$ & $\boldsymbol{V}$ \\
\hline & N'Dhala Gorge & Nature Park & $\checkmark$ & $\checkmark$ & $\boldsymbol{V}$ \\
\hline & Nitmiluk & NP & $\checkmark$ & $\checkmark$ & $\checkmark$ \\
\hline & Uluru & $\begin{array}{l}\mathrm{NP} \\
\mathrm{WH}\end{array}$ & $\boldsymbol{v}$ & $\checkmark$ & $\checkmark$ \\
\hline & $\begin{array}{l}\text { Wallace Rockhole } \\
\text { Tourist Park }\end{array}$ & $\mathrm{AL}$ & & $\checkmark$ & \\
\hline & $\begin{array}{l}\text { Yeperenye/Emily } \\
\text { and Jessie Gaps }\end{array}$ & Nature Park & $\boldsymbol{v}$ & $\boldsymbol{v}$ & $\checkmark$ \\
\hline \multirow{7}{*}{ Queensland } & Carnarvon Gorge & NP & & $\checkmark$ & $\checkmark$ \\
\hline & Chillagoe-Mungana Caves & NP & & & $\checkmark$ \\
\hline & $\begin{array}{l}\text { Flinders Group Islands } \\
\text { (Stanley Island) }\end{array}$ & NP & $\boldsymbol{v}$ & & $\checkmark$ \\
\hline & Hope Vale & $\mathrm{AL}$ & & $\checkmark$ & \\
\hline & Normanby Station & $\mathrm{AL}$ & & $\checkmark$ & \\
\hline & $\begin{array}{c}\text { Split Rock, East Quinkan } \\
\text { Reserve }\end{array}$ & $\begin{array}{c}\text { AL } \\
\text { NHL }\end{array}$ & & $\checkmark$ & $\checkmark$ \\
\hline & West Quinkan Reserve & $\begin{array}{c}\text { AL } \\
\text { NHL }\end{array}$ & & $\boldsymbol{V}$ & \\
\hline \multirow[t]{3}{*}{ South Australia } & $\begin{array}{c}\text { Anangu Pitjantjatjara } \\
\text { Yankunytjatjara } \\
\text { (APY) Lands }\end{array}$ & $\mathrm{AL}$ & & $\checkmark$ & \\
\hline & Ikara-Flinders Ranges & NP & $\checkmark$ & $\checkmark$ & $\checkmark$ \\
\hline & $\begin{array}{c}\text { Ngaut Ngaut } \\
\text { Conservation Park }\end{array}$ & $\mathrm{R}$ & & $\checkmark$ & \\
\hline Tasmania & $\begin{array}{l}\text { Tasmanian Wilderness } \\
\text { World Heritage Area }\end{array}$ & WH & & $\checkmark$ & \\
\hline Victoria & Grampians- Gariwerd & NP & & $\boldsymbol{V}$ & $\checkmark$ \\
\hline \multirow{2}{*}{ Western Australia } & Mitchell River & NP & $\checkmark$ & $\checkmark$ & $\checkmark$ \\
\hline & Murujuga & $\begin{array}{c}\text { NP } \\
\text { NHL }\end{array}$ & $\checkmark$ & $\checkmark$ & $\checkmark$ \\
\hline
\end{tabular}

\section{Rock Art Tourism in the Quinkan Region, Cape York, Queensland}

The Laura Basin ${ }^{2}$ contains thousands of rock art sites in a spectacular setting of sandstone escarpments, plateaux, valleys and gorges. The region is best known for its Quinkan (aka "Laura") style rock art, named for the unique spirit figures which are prominent in local art and mythology. Traditional Owners are associated with several contemporary Aboriginal language groups and multiple clans (Cole 2016). The rock art is represented on the National Heritage List (NHL) as "Quinkan Country", "a dynamic cultural landscape that demonstrates how Aboriginal peoples adapt and modify their traditions, kin structures and practices to maintain their connection to country, culture and identity" (Department of the Environment and Energy n.d.). The NHL area encapsulates several pastoral properties and the "Quinkan Reserves" Aboriginal lands, though Quinkan rock art extends well beyond the registered NHL boundary. In the heart of Quinkan Country is the town of Laura

2 Its onshore component comprises an area of c. $19,000 \mathrm{~km}^{2}$. 
(population c. 100), situated c. $100 \mathrm{~km}$ west of Cooktown, the main town of the Cook Shire. The region is located c. $330 \mathrm{~km}$ north of Cairns, the centre of the "Tropical North Qld" tourist zone principally known for Great Barrier Reef and rainforest travel.

\subsection{The Origins of Laura Rock Art Tourism}

Although the history of tourism barely registers on the long timeline of Quinkan rock art it represents a significant turning point in the "use" of the region's cultural heritage. The presence of rock art at Split Rock, located $14 \mathrm{~km}$ south of Laura, was first publicised in 1960 during construction of the road which introduced seasonal road access to Cape York. The origins of Laura rock art tourism lie in the early 1970s, when public advocacy for conservation and Aboriginal land rights was gaining national momentum (Cole and Buhrich 2012; Trezise 1973, pp. 203-6). Percy Trezise, who spent his life documenting and publicising rock art of the Laura-Cooktown area, became a vocal advocate for its conservation. He was instrumental in organising a meeting in 1970 called by Aboriginal leaders Dick Roughsey (Goobalathaldin) and Margaret Valladian, members of the Advisory Committee for Aboriginal Arts, an affiliate of the Australian Council for the Arts (ACA). The meeting at "the Laura Aboriginal settlement" (the "Old Reserve") resulted in formation of the Aborigines Historic Places Trust, its purpose being to "appoint its own Aboriginal rangers to protect the art sites and ... exploit the growing streams of tourists" (Trezise 1973, p. 204). Subsequently, the ACA commissioned a feasibility study of the Trust proposal and the ways in which it might benefit local Aboriginal people. Rather than addressing the basic issue of socio-economic feasibility, the study assumed that tourism was inevitable (Trezise 1973, pp. 204-6), and the views of local Aboriginal people were not mentioned. Trezise (1973, p. 205) noted that Dick Roughsey "approved the opening of selected sites so that jobs as rangers and guides would be open to local Aborigines, most of whom were unemployed".

Following the recommendations, the Commonwealth government funded the purchase of freehold land in Laura and the building of tourism infrastructure. From 1973 an Aboriginal ranger was stationed in Laura, although it is not clear if or when local people were appointed. The government sponsorship of tourism is surprising given that Laura was a remote outpost visited only by a "few brave tourists ... in the dry season" (Trost 1979, p. 10). Perhaps one of the drivers was "Cape York fever", which was said to infect city dwellers exposed to "pristine nature" and "untouched wilderness" for the first time (Trezise 1973, p. 206; Trost 1979, p. 8).

Apparently, these developments did not result in an influx of tourists. Nevertheless. the conservation campaign continued in the form of a (successful) public appeal to purchase parts of Crocodile Station for a national park (Cole and Buhrich 2012). For bureaucratic and evidently political reasons the national park failed to eventuate on the acquired lands. Instead, the Qld government established the Quinkan Reserves through a convoluted legislative and bureaucratic process, see (Cole and Buhrich 2012) in which Laura Aboriginal people were "ignored" (Ucko 1983, p. 36). The lands were managed by Qld Department of Aboriginal and Islander Affairs (DAIA), which belatedly, in 1983, appointed an Aboriginal advisory panel at Laura to manage tourism, although in effect the bureaucratic system continued as before.

\subsection{Developing Community-Based Tourism}

This is our place. Our country. The country of our ancestors. The spirit of our ancestors live here. In the rocks. These sandstone escarpments. (George et al. 1995, p. 1)

With the passage of the Aboriginal Land Act 1991 (Qld) the tide belatedly turned. The Quinkan Reserves were divested to Aboriginal Land Trusts as inalienable freehold lands. The Laura-based Ang-Gnarra Aboriginal Corporation (AAC) inherited some of the assets and responsibilities of the Quinkan Reserves Trust, as well as expectations that tourism would continue. With no means of financing these roles, AAC in association with the Qld Dept of Environment and Heritage commissioned a conservation management study as a basis for making funding applications (Sullivan 1992). With visitor management identified as a high priority, AAC established a ranger team who were advised 
by Elders, trained through a technical education scheme and employed through the Community Development Employments Projects (CDEP). ${ }^{3}$ As well as their land care duties the rangers guided tourists to Giant Horse and Mushroom Rock art sites, ${ }^{4}$ maintained tourist facilities and produced interpretive materials, e.g., (Ang-Gnarra Aboriginal Corporation 1996; George et al. 1995). As they were unable to maintain a daily presence at Split Rock, the rangers installed an "honesty box" to collect fees from tourists. In spite of their tenuous financial base, the ranger team functioned effectively and became widely respected for their leadership in land care and cultural tourism. In recognition, Senior Rangers and Elders Tommy George (1929-2016) and George Musgrave (1920-2006) were awarded Honorary Doctorates by James Cook University.

AAC was restructured c. 2000, resulting in the ranger program being put on hold. Around this time, the state and Commonwealth governments announced development of the Qld Heritage Trails Network (QHTN), a Commonwealth-funded capital works project to provide cultural tourism opportunities. At Laura the QHTN development, an interpretive centre, was predictably fraught, given the "top down" government approach which inspired it. The process included a management review which recommended that a cultural heritage management system be integrated with the centre's proposed tourism operations, following stated best practice of QHTN (Cole and Horsfall 2003; Cook n.d.). The recommendation was not followed, and the centre opened solely as an interpretive display and tour hub. A decade after its opening the Quinkan and Regional Cultural Centre (QRCC) was unable to offer employment beyond casual, seasonal work for Aboriginal people as tour guides (Marsh and Musgrave 2013), a situation which remains unchanged.

In 2010, a new ranger team (the Laura Rangers) was formed in association with a Cooktown based non-government natural resource agency, South Cape York Catchments (SCYC). The Laura Rangers are employed through the Queensland Indigenous Land and Sea Rangers Program, a valuable (if rare) form of government investment in community cultural aspirations. The mission of the Laura Rangers, as expressed in "Laura River Dreaming" (Marsh and Musgrave 2013), is to continue the tradition of caring for country and rock art. A core element is to oppose the ongoing threat of mining development. This mission has been relatively successful, and as a result of a concerted campaign by the Laura Rangers, their community and colleagues assisted by the national media, several major mining applications were withdrawn, and an alluvial gold mining proposal for the Laura River valley rock art precinct failed to proceed. As threats continue, the community continues the battle to preserve the integrity of the landscape, which is essential to their wellbeing ${ }^{5}$ and future. It is largely due to the efforts of the Laura Rangers that "Quinkan Country" was inscribed on the NHL in 2018. Importantly, the inscription recognizes that apart from its remarkable aesthetic, scientific and traditional cultural values, the significance of Quinkan rock art is strongly tied to contemporary community values. Although the listing does not provide blanket protection, it offers an avenue of objection in the event of threats to values inscribed under the Environmental Protection and Biodiversity Conservation Act 1999 (the EPBC Act).

The Laura Rangers conduct an integrated work program of cultural mapping, rock art recording and monitoring, stream monitoring, weed and erosion control and fire management (George 2013), sometimes in consultation with external specialists (Buhrich and the Laura Rangers 2017). Their community outreach activities include engaging with the Laura school to promote cultural education, and coordinating the Laura Cultural Heritage Body, a group of stakeholders, friends and associates whose shared goal is to protect Laura rock art and cultural heritage. Far from being marginal, such

3 Also known as "work for the dole".

4 The major site known as "the Quinkans" was originally closed to tourism for cultural reasons (George et al. 1995); tours to this site are now advertised.

5 We refer to a holistic view of health that recognizes that connection to country, culture, family, and community, together with policies and past events, can impact on personal and social wellbeing, see (Altman 2003; Sutherland and Adams 2019; Yap and Yu 2016). 
activities are central to upholding the community values which underpin successful rock art tourism (Deacon 2006).

\subsection{A Grass-Roots Initiative}

Our grandfather told us the stories of our country. We like to share these stories to keep them alive. (Dylan Harrigan, Balnggarrawarra Traditional Owner; Culture Connect n.d.)

In 2017 an extended family of Balnggarrawarra Traditional Owners launched small-scale commercial tours on Normanby Station, a pastoral lease owned by the Normanby Aboriginal Corporation. The 34, 500 ha station is located west of Cooktown and includes parts of the Normanby River and surrounding escarpments and uplands, with abundant rock art in the Quinkan regional style. As well as having rich natural and cultural values, Normanby is of historical significance due to its strategic location between Cooktown and the Palmer River goldfields. The legendary battle of the Normanby which heralded the goldrush invasion in 1873, occurred there, and the first "rush" track runs across the property, as did the historic Cooktown to Laura railway line. Normanby was an early cattle station of the Cook District and the site of Native Mounted Police camps, which were military bases for the frontier war.

As with their land care projects (Hartwig 2017) "this [tourism initiative] was their project ... for them to own". The Balnggarrawarra tours include an interpretive visit to rock art sites that are otherwise inaccessible to the public. The size of tour groups is limited to the 18 seat capacity of a four wheel drive (off-road) vehicle, which provides transport ex-Cooktown. During a 20 min bush walk, guides discuss features such as traditional bush tucker and medicine plants, and explain their traditional connections to country and the cultural significance of the rock art. The day tour includes visits to locations where the guides, who have dual roles as rangers, explain their land care activities, such as erosion mitigation works, fire regimes, and destocking and fencing policies to restore vulnerable areas. The itinerary includes a visit to Battle Camp, where tourists have a rare opportunity to learn Australian history from a Traditional Owner perspective. Balnggarrawarra people would like tourists to come away with an understanding of the ways in which their rangers are integrating cultural, natural and scientific knowledge in their contemporary land management and cultural tourism operations.

Of course, small grass-roots entrepreneurial businesses of this type are not without their problems (Bennett and Gordon 2007). To assist with administration and co-ordination with the Qld Indigenous Land and Sea Program, Balnggarrawarra operate in association with SCYC, and for tourism, they have developed another partnership (see below). The participation of two generations of an extended family further enhances capacity and provides pathways for training and succession.

\subsection{Challenges and Realities}

Tourism requires not only attractions but access (Du Cros and McKercher 2015), an amenity which, for both Cape York and Kakadu (see the following section), is limited by the factors of remoteness and seasonality, which are usually negatives for the tourism industry (Butler 2002; Tonnaer 2010). To access the rock art, visitors must drive for several hours or take air charters from Cairns to Laura or Cooktown to join a 4WD tour. Access and seasonality are particularly challenging to small scale operations. Hence the Balnggarrawarra enterprise has formed a linkage with a cultural tourism operator to provide a flow of tourists and manage bookings and logistics from the regional centre of Cairns.

As most rock art is readily accessible via public roads, a major challenge is the maintenance of unsealed vehicle tracks which regularly deteriorate in the wet season. Walking tracks, some of which in the Laura area are now closed for safety reasons, also require regular monitoring and repair. At Split Rock, the inadequacy of the "honesty" system of fee payment is apparent (Quinkan and Regional Cultural Centre 2019). Although visitor books are no longer kept at the site, internet sources such as TripAdvisor provide feedback, and while comments relating to the rock art are overwhelmingly favourable, those on infrastructure can be less so.

The vision of the Laura Rangers, while prioritising the development of a sustainable local economy based around eco-tourism, also recognises the implications of expanding tourism (Marsh and Musgrave 
2013). Management of "public" sites remains an issue of concern, as is the problem of unauthorised camping by four-wheel-drive travellers. Although expansion of the ranger workforce is desirable, it is constrained by an overcrowded housing situation which reduces the incentive for young people to live at Laura (S. Marsh pers. comm.). Although ranger jobs offer significant social, economic, cultural and health benefits, e.g., see (Central Land Council n.d.), the requisite physical fitness can limit the capacity of some community members to work in these roles. Hence socio-economic factors, including health conditions which affect Indigenous Australians at higher levels than their non-Indigenous counterparts (NACCHO 2019), can be limiting factors for community development.

Some of the challenges faced by the Laura community are indicative of a wider issue: the capacity of a small, remote community to meet, in some cases free-of-charge, the expectations of the mainstream tourist industry. Although the Commonwealth provides short term competitive grants to manage heritage listed properties, intermittent grants are inadequate for the standards of presentation and visitor management appropriate to Quinkan rock art (Cole and Buhrich 2012). It has been difficult for the community to manage the separation of land care and conservation activities from the commercial operations of the QRCC, and as Laura is a town with multiple stakeholders, governance is not clearcut. On the positive side, Laura's social capital of community organisations (including land trusts, the Laura Rangers, AAC, QRCC, Laura Cultural Heritage Body, and Laura State School) and wider partnerships represent a sound basis for funding applications.

Every two years, the Aboriginal community hosts the Laura Dance Festival on a traditional "bora" ground on the banks of the Laura River, in close proximity to Split Rock. The combination of cultural performances, visits to rock art and opportunities to meet people from many Cape York communities represents the ultimate experience in cultural tourism. However, it is likely that few festival visitors would be aware of the long-term contributions, achievements and aspirations of the Laura Aboriginal community, who are champions of community care for rock art: "People who know, love and benefit from their heritage would naturally be in the front line to preserve it" (Little and Borona 2014, p. 181). To date, the benefits to Laura people are in the form of cultural and social wellbeing rather than financial reward.

\section{Rock Art Tourism in Kakadu National Park, Northern Territory}

Some 1200 km west of Laura is Kakadu National Park (KNP or "the Park"), Australia's largest national park, covering nearly 20,000 square kilometres of land in the Alligator Rivers region area of the NT. The northwestern half of KNP is characterised by low-lying plains and wetland systems, while the southeast is dominated by spectacular sandstone escarpment country that contains $>6000$ recorded rock art sites. Much of the tourism is centred on Jabiru (population c.1100 people), located $250 \mathrm{~km}$ east of Darwin and adjacent to the Bowali Visitor Centre at the entrance of the Park. Although Jabiru is connected to major rock art sites via sealed roads, access is typically cut during the "Wet". Hence the tourist season in KNP, as in Cape York, is highly seasonal.

\subsection{The Origins of the Jointly Managed KNP}

The establishment of KNP in 1979 was strongly influenced by the conservation movement, the Aboriginal land rights movement and, more controversially, uranium mining. The concept of a national park in the Alligator Rivers region was first mooted in 1965 (Director of National Parks 2016, p. 5; Fox et al. 1977, pp. 197-207; Wellings 2007, p. 91). In December 1973 the then Prime Minister, Gough Whitlam, announced that Cabinet had agreed to establish the national park, the proposed boundaries of which were notified in 1975 (Fox et al. 1977, p. 202). At play in the background was the demand for NT self-government and two major Commonwealth Government inquiries-the Woodward Inquiry into Aboriginal Land Rights Commission and the Fox Ranger Uranium Environmental Inquiry.

The Woodward Inquiry was established to inquire into appropriate ways to recognise Aboriginal land rights in the NT while also providing for conservation management (Woodward 1973). With regard to the latter, in some areas "worthy of special protection" the commission concluded that "a 
scheme of Aboriginal title, combined with national park status and joint management should be acceptable" (Woodward 1974, p. 95). Based on the final recommendations (Woodward 1974), the Aboriginal Land Rights (Northern Territory) Act 1976 (the Land Rights Act) was subsequently passed. The legislation paved the way for the recognition of Aboriginal property rights in the Alligator Rivers region. The hearing of the land claim was conducted by Fox et al. $(1976,1977)$, in conjunction with an inquiry into the proposals for uranium mining and the creation of a national park (Giblin 2004; Graetz 2015; O'Faircheallaigh 2012).

Subsequently, KNP was established under the National Parks and Wildlife Conservation Act 1975 (the NPWC Act) in three stages between 1979 and 1999, each stage representing the outcome from a successful land claim; thereafter, the land was leased back to the Director of Parks to be included as part of KNP. Certain areas with uranium deposits (Ranger, Jabiluka, and Koongarra) were excluded from the Park; mining commenced at Ranger and the township of Jabiru was constructed in the early 1980 s as a service centre for the mine.

In recognition of the universal natural and heritage values of the region, Stage One of KNP was inscribed on the World Heritage List (WHL) in $1981^{6}$. Rock art, representing a masterpiece of human creative genius under Criterion (i), was a key element of the inscription:

$\ldots$ because of the wide range of styles used, the large number and density of sites and the delicate and detailed depiction of a wide range of human figures and identifiable animal species, including animals long-extinct. (Director of National Parks 2016, p. 188; UNESCO World Heritage Centre 2019)

Unsurprisingly, rock art in the excluded mineral areas is contiguous with WH listed rock art in the Park. Jabiluka, the location of the outstanding archaeological site of Madjedbebe (Clarkson et al. 2017), contains highly significant rock art, as does Koongarra.

From c. 1994, in response to community concerns and well-orchestrated lobbying from the Mirarr people, the World Heritage Committee of ICOMOS/IUCN sent missions to the Park to assess impacts of mining and inquire into other conservation issues (Fagan 1999; Maswood 2000). Despite Mirarr concerns and the intention to proceed with the Jabiluka mine, the World Heritage Committee in 2001 rejected the expert findings and chose not to add KNP to the World Heritage in Danger list (Logan 2013), to the relief of the Australian Government. Owing to a change in ownership of the Jabiluka mining lease and in response to public and Traditional Owner opposition, early construction works were halted at Jabiluka in 2001. Mining never commenced at Koongarra, which was added to the WHL area in 2013 after intense lobbying by Djok Traditional Owner Jeffrey Lee and others (Director of National Parks 2016, p. 9). Ranger mine is scheduled for closure by early 2021 (ERA 2018).

Today, approximately half of the land comprising the Park is "Aboriginal land" under the Land Rights Act, held by Aboriginal Land Trusts and leased to the DNP, operating as a national park under the EPBC Act. Management of this land is via the KNP Management Plan (2016-2026) (Director of National Parks 2016), under a Director working to a Board of Management. Although the latter is required to have an Aboriginal Chairperson and a majority of Aboriginal members who are nominated by the Traditional Owners (Director of National Parks 2016, p. 31), the structure does not necessarily align with Traditional Owner group structures and priorities. Today, Traditional Owner groups have established their own ranger groups and land management plans with varying levels of formality and support. This complex evolution of Traditional Owner entities and ranger groups is actively continuing without specific acknowledgment in the Management Plan. KNP rangers referred to in the Management Plan are employees of Parks Australia and not Traditional Owner ranger groups. There is no requirement for the rangers to be members of the Traditional Owner group for land on which they work, and their work programs are determined by Park administrators rather than Traditional Owners.

6 Extensions also occurred in 1987, 1992 and a minor boundary modification in 2011. 
The Management Plan refers extensively to traditional Aboriginal law and custom but lacks practical mechanisms for Traditional Owner entities or ranger groups to transact with park management. There are numerous Aboriginal clan groups represented in the Park, and at least 18 outstations where the majority of the c. 500 Aboriginal residents live. The Management Plan, however, engages with Aboriginal Traditional Owners collectively as "bininj/mungguy". Management decisions are made despite, and sometimes in conflict with, Traditional Owner ranger group plans and other Traditional Owner corporation initiatives.

\subsection{Rock Art and Tourism in KNP}

Kakadu is promoted internationally as a key Australian location where visitors can experience Aboriginal rock art as part of a living culture that extends back at least 60,000 years (Clarkson et al. 2017). Although Aboriginal people recognise that tourists are interested in visiting this rock art, and that there are potential benefits through this, "the notion of travelling long distances to see someone else's country as a form of recreation" did not exist in traditional Aboriginal society (Wellings 1995, pp. 253-54). As Woodward (1974, p. 92) reported in the context of his inquiry, the attitude of Aboriginal communities in the NT to tourism was

... varied. Some communities have shown opposition or, at least, disinterest. Others have actively encouraged it, especially where the sale of artifacts [sic] now constitutes a significant source of income.

Nevertheless, tourism has been a feature of the Alligator Rivers region since at least the 1950s, when "safari camps" were established to afford tourists the opportunity to meet local people, view rock art, and go fishing and hunting (Wellings 2007, p. 92). In considering the issue of Aboriginal land rights, Woodward (1974, p. 89) observed that tourism "has a good deal to offer Aborigines in material terms", without elaborating upon the benefits. Accordingly, the tourism issue was specifically addressed in the Fox Report, with (Fox et al. 1977, p. 209) noting that rock art, specifically the sites of Nourlangie and Obiri [Ubirr], was a "popular attraction" and that a national park had potential to protect Aboriginal lands and culture from unwanted intrusions of tourists.

Toby Gangale (a now deceased Traditional Owner of the Mirarr estate who was formerly employed as a cultural advisor to KNP) noted that he was "very happy to have this national park here ... Tourists can come up here and enjoy themselves ... look at cave paintings ... ", though he emphasised that visitor access to sacred sites, Dreaming places and burial places needed to be controlled (Gangale 1984, p. 57). Likewise, Bill Neidjie (a now deceased Traditional Owner of the Bunitj estate) was supportive of rock art tourism, provided it was managed effectively:

I like visitors to come to Ubirr to look at the paintings and learn the stories about the paintings

... I think that as long as people don't go where they shouldn't, and if the Aboriginal stories are told well, then visitors in moderate numbers are alright. (Neidjie 1984, pp. 41-42)

Accordingly, Traditional Owners agreed to open three sites ${ }^{7}$ within KNP for public visitation: Burrungkuy (Nourlangie Rock) and Nanguluwurr (in the Nourlangie region) and Ubirr (East Alligator region). Ubirr in particular is considered a "must see" destination, not only for its outstanding rock art but for the spectacular outlook which affords breathtaking sunset views over the wetlands. Boardwalks and interpretative signage approved by Traditional Owners facilitate visitor access and enjoyment. While these sites are primarily accessed via self-guided walks, on occasion KNP rangers will provide guided tours. Of these three public access sites only Ubirr has an official rock art conservation plan (Gillespie 1982), though Marshall (2019) recently prepared advice to assist Traditional Owners managing Nanguluwurr from a rock art perspective.

7 Blue Paintings ("Little Nourlangie"), was formerly opened to public access, but closed in the 1990s owing to the sensitive environment and concerns of Traditional Owners. 
For a brief period (c. 2014-2016), the then newly formed Njanjma Rangers, ${ }^{8}$ operating under the auspices of the Djabulukgu Association Inc., secured a contract from Parks Australia to undertake visitor surveillance, management activities and seasonal interpretive tours at Ubirr. Despite some teething problems, the Indigenous-led interpretive tours were a genuine "smash hit" with tourists. Unfortunately, for various reasons, Parks Australia did not renew the contract; however, there are indications of renewed negotiations with regard to Aboriginal management and tourism opportunities at Ubirr.

One of the region's most successful grass-roots rock art tourism ventures operates outside the Park: the Bininj [Aboriginal]-led rock art tours to Injalak Hill, operated by the Indigenous owned Injalak Arts and Craft centre in Gunbalanya on Aboriginal Land Trust land in West Arnhem Land (adjacent to northeast KNP). Although the tour is seasonal, it is a rare opportunity to visit rock art sites with knowledgeable Traditional Owner guides who delight in sharing their Country and culture with visitors. However, as external tour operators are not always successful in their endeavors to engage local Bininj guides, some tours may lack this key aspect of the experience.

\subsection{Challenges and Realities}

A survey conducted in October 2010 found that, "bushwalking (including short walks to art sites) was the first priority of planned activities by domestic and fourth highest priority for international visitors (after photography, rock art viewing and wildlife viewing)" to KNP (as cited in Inspiring Place 2015, p. 26). Unsurprisingly therefore, bushwalking and access to "wilderness" are key elements of KNP tourism promotion, with Kakadu being considered one of the "major bushwalking destinations in the Top End" (Director of National Parks 2016, p. 102). However, Aboriginal concerns about unaccompanied bushwalkers were raised before the Park was established (Chaloupka 1978; Palmer 2004, p. 112; see also Gabirrigi 1984). Despite Traditional Owners wishing to restrict visitation to the "public" sites, visitors can, and routinely do, access other rock art sites via established bushwalking tracks. Aboriginal concerns in this regard have largely gone unheeded, driven by Park Management aspirations to promote nature-based tourism and increase visitor numbers. The Management Plan is inconsistent on the matter as, under the EPBC Regulations, "walking off a public road or track is prohibited" yet,

Opportunities for overnight bushwalks are provided in the stone country of the Park. These are undertaken along unmarked routes that have been identified by Bininj/Mungguy ... permits ... [are] required for all overnight walks. (Director of National Parks 2016, p. 170)

As Palmer (2004, p. 112) pointed out, a key issue in this regard is that

... these routes were established by bushwalkers themselves; Bininj/Mungguy did not plan them, and most would never have walked them. Bininj/Mungguy do not practice bushwalking in the European sense.

It is a reflection of the Kakadu arrangements and the NT heritage legislation, that such routes have never been subject to comprehensive cultural heritage clearance. The situation is exacerbated by the lack of an effective mechanism for Park Management to engage directly with Traditional Owner rangers and entities in management planning.

The number of bushwalking permits issued at any one time is limited, and the only stipulation for permit holders is that they do not "touch or interfere with any rock art, sacred site, or cultural artefact". In effect, bushwalkers can "do as they please" (Palmer 2004, p. 116). In the Djidbidjidbi (Mount Brockman) area, a premier bush walking area, Mirarr Traditional Owners continue to express grave concerns about disrespectful and unmonitored visitation (Skitmore et al. 2015, p. 9).

8 Njanjma Rangers is a Traditional Owner controlled entity now separately incorporated and part of the recognised Working on Country network. 
The current Management Plan (Director of National Parks 2016, p. 103) notes visitor interest in engaging with local people, for example by “... participating in the ranger walks and talks, engaging a Bininj/Mungguy guide or joining a Bininj/Mungguy tour ... to hear traditional stories and learn about the living Indigenous culture in the Park", see also (Hampson 2015) in relation to similar tourist interests at South African rock art places). Woodward (1974, p. 93) recognised from the outset that "Aboriginal rangers and guides should be employed as appropriate to control and assist tourists". Disappointingly for many tourists, the KNP ranger guides are predominantly casual Balanda (non-Aboriginal) staff employed on a seasonal basis. In reality, opportunities to engage with Bininj/Mungguy people outside special events (such as Taste of Kakadu and Mahbilil festivals) are limited. An exception is the Kakadu Cultural Tours (KCT) enterprise owned and operated by the Djabulukgu Association Inc., (Jabiru, Australia) though many of their tours are nature based and/or more broadly culturally based, rather than being rock art focused.

Although joint management is promoted as a positive element of KNP and is a point of difference from Quinkan Country, the reality is that Indigenous aspirations are not well-realised in the day-to-day operation of the Park (Hehir 2019, p. 36; see also Smyth 2001; Wearing and Huyskens 2001). A recent audit revealed major deficiencies identified by Traditional Owners and/or other individuals and organisations involved with Aboriginal communities in KNP in their relationships with Park managers (Hehir 2019, pp. 35-36). A further complaint was a "lack of employment pathways and training for Aboriginal and Torres Strait Islander people to assist them to progress beyond entry level positions" (Hehir 2019, p. 25). In terms of direct employment within Parks Australia, the regulatory authority presiding over KNP, “Aboriginal and Torres Strait Islander staff represent just 15 per cent of ongoing, 31 per cent of non-ongoing and 60 per cent of casual staff" (Hehir 2019, p. 48).

In KNP, an annual income of several million dollars derived from visitor fees, rent from the Federal Government and direct employment must be shared amongst c. 500 Aboriginal residents (Haynes 2010, pp. 172-73). These monies represent a fraction of those generated through KNP tourism. With only a small proportion of KNP visitors engaging with rock art or participating in Aboriginal-led tours, the very concept of rock art tourism in Kakadu is tenuous despite its prominence in tourism marketing.

\section{Conclusions}

Although visitation to Australian rock art "destinations" is small on the global scale, the contexts and operating modes are diverse, as are the challenges. Yet, as a national industry, rock art tourism suffers from inadequate information from which to draw policy. For example, there is a lack of accurate data on visitation, whether it be intentional or ancillary. As in the case of wider studies of Indigenous tourism (Whitford and Ruhanen 2017, pp. 14-15), there is a need for reliable data and realistic market analysis in order to provide useful industry support for both existing and potential Indigenous rock art tourism providers and stakeholders. Systematic cultural heritage survey work on country is also required to provide data that better reflects the real potential for rock art tourism.

In our introductory survey, we identified relatively few Indigenous business enterprises conducting specialised rock art tours. Reasons for this apparently limited participation may lie in the usual difficulties of developing a "small and remote business" (Brereton et al. 2007, p. 14) and/or the types of cultural, socio-economic, and governance factors which are said to inhibit Indigenous tourism (Brereton et al. 2007; Hodgson et al. 2007; Novelli 2004; Whitford and Ruhanen 2009). However, this type of operation is but one reality of a heterogeneous industry which is often represented by Indigenous rangers, Traditional Owner Corporations, and families for whom tourism is a supplementary activity. Host communities, in providing approvals and oversight, form another essential tier of rock art tourism.

The Laura and KNP case-studies identified some common environmental, socio-economic, cultural and political themes in the origins of tourism. Although the trajectories diverged, largely as a result of high-level political decisions on land tenure, land management and Traditional Owner engagement, common legacies and challenges endure. Mining played a central role in in the controversial process of developing KNP, and threats of mining are ongoing in the Quinkan region. In both areas, rock 
art tourism was entrenched via top down decision making. However, in the transformative years following the Qld Aboriginal Land Act (1991), the Laura people converted a paternalistic, bureaucratic model of poor returns to a community-owned system that operates with scarce resources. In spite of setbacks, the "Laura mob", as they are widely known, have continued to apply their capacity as a community to long-term land and heritage protection, a cause for optimism with regard to their aspirations of developing sustainable tourism. Achieving the latter, as in any form of community development, requires decisions to be made locally and autonomously rather than imposed from outside (Fuller and Gleeson 2007). The recent inscription of Quinkan Country to the NHL is the realisation of decades-old aspirations and enterprise by the Laura mob to achieve recognition of their rock art and their primary role in managing and promoting it.

The Aboriginal communities of KNP also inherited tourism, but, unlike at Laura, KNP operates with comparatively substantive and complex physical and planning infrastructure which should offer a sound basis for rock art tourism. On the contrary, however, the competing values of the bureaucracy weigh heavily on Traditional Owner communities, presenting a complex context for operating rock art tourism. The difficulties are compounded by the exclusion of Traditional Owner governance structures from Park operations (Hehir 2019), together with a lack of cultural heritage data to support decision-making and to manage visitor impacts and commercial expectations. As at Laura, Traditional Owners appear to receive limited employment and financial benefits from rock art tourism. These realities are indicative of enduring inequities in the economics of tourism and the presentation and management of Indigenous rock art.

Deacon (2006, p. 2) has observed that "management of rock art tourism is dependent on the different individuals and organisations agreeing on the broad values and principles and on the conservation principles that need to be met". In spite of joint management principles and Indigenous representation on the Board of Management in KNP, achieving this type of consensus is clearly a challenge. Managing tourism in KNP has become increasingly complex as a result of the emergence of autonomous Indigenous corporations representing Traditional Owner communities.

Although this study presents different scenarios, an intrinsic, unifying theme is the Traditional Owner priority of caring for rock art in the contemporary context. Brereton et al. (2007, p. 10) noted the potential of combining the roles of Aboriginal tour guide and ranger, not only as a partial solution to seasonal fluctuations in tourism (which are particularly evident in our study areas), but because Aboriginal methods of caring for country "are potential attractions in their own right". This type of system, that is, the integration of Indigenous land management and cultural tourism, was developed and operated in Laura in the 1990s through local Traditional Owner initiatives and agency support. It was successfully, if briefly, operated at KNP by the Traditional Owner rangers c.2014-2016. At Normanby Station, the role of Owner/ranger/tour guide is a centerpiece of an autonomous Indigenous tourism enterprise. In drawing upon the customary, state and market sectors, the approach reflects Altman's model of sustainable Indigenous tourism within a hybrid economy framework (Altman 2001, 2005, 2009). The features of Traditional Ownership and control, linkages, cultural preservation and transmission, and emphasis on the heritage of the owner community are characteristic of sustainable tourism (Butler and Hinch 2007; Deacon 2006; Smiechen and Boyle 2007; Whitford and Ruhanen 2009). For tourists, this type of experience is well placed to offer the much discussed quality of authenticity by presenting rock art within an integrated real time context of Aboriginal Ownership, values and connections, contemporary land care, jobs, and everyday lifestyles. As Traditional Owners have shown, the rock art tradition is inextricably linked with communicating their identity, connections, and responsibilities to the land. In this way, the combination of Traditional Owner ranger work with tourism represents an extension of a cultural tradition rather than a competition of values.

Author Contributions: N.A.C. wrote the section on Cape York (Qld); L.A.W. wrote the section on Kakadu National Park (NT). Both authors co-ordinated these sections and wrote the introductory and concluding sections.

Funding: This research received no external funding. 
Acknowledgments: N.A.C. has worked with the Laura Aboriginal community for many years as an archaeologist. L.A.W. works as a Cultural Heritage Advisor to Gundjeihmi Aboriginal Corporation (GAC), who represent the Mirarr people, though the opinions expressed in this paper regarding KNP do not necessarily represent the views of GAC or the Mirarr people. N.A.C. and L.A.W. have worked with the Laura Rangers and Balnggarrawarra Rangers in recent research projects. We thank the Laura Rangers, Sue Marsh, Jason Carroll, Vincent Harrigan, Melissa Marshall, Alice Buhrich, the Djurrubu Rangers, May Nango, Djaykuk Djandomerr, Matt Rawlinson, Susan O'Sullivan, Justin O'Brien, Sean Spicer, Liam Maher, Shay Wrigglesworth, James Dempsey, Alfred Nayinggal and Glen Maclaren for helpful discussions regarding rock art tourism. The views presented here are those of the authors.

Conflicts of Interest: The authors declare no conflict of interest.

\section{References}

Abascal, Trinidad E., Martin Fluker, and Min Jiang. 2016. Domestic demand for Indigenous tourism in Australia: Understanding intention to participate. Journal of Sustainable Tourism 24: 1350-68. [CrossRef]

Agnew, Nicholas, Janet Deacon, Nicholas Hall, Terry Little, Sharon Sullivan, and Paul Taçon. 2015. Rock Art: A Cultural Treasure at Risk. Los Angeles: The Getty Conservation Institute.

Altman, Jon C. 1989. Tourism dilemmas for Aboriginal Australians. Annals of Tourism Research 16: 456-76. [CrossRef]

Altman, Jon C. 2001. Sustainable Development Options on Aboriginal Land: The Hybrid Economy in the Twenty-First Century. Canberra: Centre for Aboriginal Economic Policy Research.

Altman, Jon C. 2003. People on country, healthy landscapes and sustainable Indigenous economic futures: The Arnhem Land case. The Drawing Board: An Australian Review of Public Affairs 4: 65-82.

Altman, Jon C. 2005. Development options on Aboriginal land: Sustainable Indigenous hybrid economies in the twenty-first century. In The Power of Knowledge, the Resonance of Tradition. Edited by Luke Taylor, Graeme Ward, Graham Henderson, Richard Davis and Lynley Wallis. Canberra: Aboriginal Studies Press, pp. 34-48.

Altman, Jon C. 2009. The hybrid economy and anthropological engagements with policy discourse: A brief reflection. The Australian Journal of Anthropology 20: 318-29. [CrossRef]

Ang-Gnarra Aboriginal Corporation. 1996. Quinkan Rock Art: Images on Rock from the Laura Area. Laura: Ang-Gnarra Aboriginal Corporation.

Bennett, Judy, and Wilfred Gordon. 2007. Social capital and the Indigenous tourism entrepreneur. In Striving for Sustainability: Case Studies in Indigenous Tourism. Edited by Jeremy Buultjens and Don Fuller. Lismore: Southern Cross University Press, pp. 333-70.

Bonet, Lluis. 2003. Cultural tourism. In A Handbook of Cultural Economics. Edited by Ruth Towse. Cheltenham: Edward Elgar, pp. 187-93.

Brereton, David, Paul Memmott, Joseph Reser, Jeremy Buultjens, Linda Thomson, Tanuja Barker, Tim O’Rourke, and Catherine Chambers. 2007. Mining and Indigenous Tourism in Northern Australia. Gold Coast: CRC for Sustainable Tourism.

Buhrich, Alice, and the Laura Rangers. 2017. Split Rock Visitor Infrastructure Assessment. Unpublished report prepared for South Cape York Catchments.

Butler, Richard W. 2002. Seasonality in tourism: Issues and implications. In Seasonality in Tourism. Edited by Tom Baum and Svend Lundtorp. London: Taylor and Francis, pp. 5-22.

Butler, Richard, and Thomas Hinch. 2007. Conclusions: Key themes and issues. In Tourism and Indigenous Peoples: Issues and Implications. Edited by Thomas Hinch and Richard Butler. Amsterdam: Elsevier, pp. 319-31.

Central Land Council. n.d. CLC Rangers: The Benefits of Ranger Work. Available online: https://www.clc.org.au/ files/pdf/CLC-The-benefits-of-ranger-work (accessed on 31 October 2019).

Chaloupka, George. 1978. Rock art deterioration and conservation in the Top End of the Northern Territory. In Conservation of Rock Art. Edited by Colin Pearson. Canberra: The Institute for the Conservation of Cultural Material, Canberra College of Advanced Education, pp. 75-88.

China Daily. 2016. Xi'an Hosts Record Numbers of Tourists. Available online: http://www.chinadaily.com.cn/ china/2016-02/27/content23666129.htm (accessed on 18 August 2019). 
Clarkson, Christopher, Zenobia Jacobs, Ben Marwick, Richard Fullagar, Lynley A. Wallis, Mike Smith, Richard (Bert) G. Roberts, Elspeth Hayes, Kelsey Lowe, and Xaviah Carah. 2017. Human occupation of northern Australia by 65,000 years ago. Nature 547: 306-10. [CrossRef] [PubMed]

Cole, Noelene. 2016. Land/people relationships and the future of rock art in the Laura Basin, northeastern Australia. In Relating to Rock Art in the Contemporary World: Navigating Symbolism, Meaning and Significance. Edited by Liam Brady and Paul Taçon. Boulder: University Press of Colorado, pp. 189-212.

Cole, Noelene, and Alice Buhrich. 2012. Endangered rock art: Forty years of cultural heritage management in the Quinkan region, Cape York Peninsula. Australian Archaeology 75: 1-12. [CrossRef]

Cole, Noelene, and Nicola Horsfall. 2003. Review and Update Conservation Management: Rock Art of the Laura Sub-region of Qld. Unpublished report prepared for Arts Qld, the Qld Heritage Trails Network, the Steering Committee of the Quinkan Interpretive Centre and Cook Shire Council.

Cook, Penny. n.d. Alliances, Linkages and Challenges: The Queensland Heritage Trails Network. Available online: https://www.aicomos.com/wp-content/uploads/Alliances-Linkages-and-Challenges-theQueensland-Heritage-Trails-Network.pdf (accessed on 18 August 2019).

Cook Shire Council Economic Profile. 2015. Available online: www.cook.qld.gov.au (accessed on 15 July 2019).

Council of Europe. 2019. Prehistoric Rock Art Trails. Available online: https://www.coe.int/en/web/culturalroutes/prehistoric-rock-art-trails (accessed on 5 July 2019).

Culture Connect. n.d. Aboriginal Experiences. Available online: https://cultureconnect.com.au/tours/4wdaboriginal-cooktown-rock-art-and-ranger-day-tour/ (accessed on 5 July 2019).

Deacon, Janet. 2006. Rock art conservation and tourism. Journal of Archaeological Method and Theory 13: 376-96. [CrossRef]

Department of Foreign Affairs and Trade. 2019. Business Envoy. Available online: https://dfat.gov.au/aboutus/publications/trade-investment/business-envoy/Pages/january-2019/indigenous-tourism-surge.aspx (accessed on 10 August 2019).

Department of the Environment and Energy. n.d. Quinkan Country. Available online: https://www.environment. gov.au/heritage/places/national/quinkan-country (accessed on 10 August 2019).

Department of Tourism, Sport and Culture NT. 2019. Park Visitor Data. Available online: https://dtsc.nt.gov.au/ parks-and-wildlife-commission/parks-and-wildlife-statistics-and-research/park-visitor-dataDu (accessed on 18 August 2019).

Director of National Parks. 2016. Kakadu National Park Management Plan (2016-2026). Canberra: Director of National Parks Australia.

Dragovich, Deirdre. 1993. Aboriginal rock art and visitors to Mootwingee National Park. Australian Aboriginal Studies 1993: 58-65.

Du Cros, Hilary, and Bob McKercher. 2015. Cultural Tourism, 2nd ed. London: Taylor and Francis.

Duval, Melanie, and Benjamin Smith. 2013. Rock art tourism in the uKhalamba/Drakensburg World Heritage site: Obstacles to the development of sustainable tourism. Journal of Sustainable Tourism 21: 134-53. [CrossRef]

Duval, Melanie, Christophe Gauchon, and Benjamin Smith. 2018. Rock art tourism. In The Oxford Handbook of the Archaeology and Anthropology of Rock Art. Edited by Bruno David and Ian McNiven. Oxford: Oxford Handbooks Online. [CrossRef]

ERA. 2018. Ranger Mine Closure Plan. Jabiru: Energy Resources of Australia.

Fagan, Matthew. 1999. UNESCO Special Mission to Kakadu National Park. Indigenous Law Bulletin 4: 16.

Fernandes, Antonio Pedro, Marta Mendes, Thierry Aubry, Jorge Sampaio, Rosa Jardim, Dalila Correia, Angela Junqueiro, Delfina Bazareu, Fernando Dias, and Pedro Pinto. 2008. The evolving relationship between the Coa Valley Archaeological Park and the local community: An account of the first decade. Conservation and Management of Archaeological Sites 10: 330-43. [CrossRef]

Fox, Russell W., G. G. Kelleher, and C. B. Kerr. 1976. Ranger Uranium Environmental Inquiry: First Report. Canberra: Ranger Uranium Environmental Inquiry.

Fox, Russell W., G. G. Kelleher, and C. B. Kerr. 1977. Ranger Uranium Environmental Inquiry: Second Report. Canberra: Ranger Uranium Environmental Inquiry.

Fuller, Don, and Anne Gleeson. 2007. Sustainable Indigenous community economic development in Australia. In Striving for Sustainability: Case Studies in Indigenous Tourism. Edited by Jeremy Buultjens and Don Fuller. Lismore: Southern University Press, pp. 1-36. 
Gabirrigi, Nipper. 1984. Back to my country. In Visitors to Aboriginal Sites: Access, Control and Management: Proceedings of the 1983 Kakadu Workshop. Edited by Hilary Sullivan. Canberra: Australian National Parks and Wildlife Service, p. 59.

Gale, Fay, and Jane Jacobs. 1987. Aboriginal art-Australia's neglected inheritance. World Archaeology 19: $226-35$. [CrossRef]

Galliford, Mark. 2011. Touring 'Country', sharing 'Home': Aboriginal tourism, Australian tourists and the possibility for cultural transversality. Tourist Studies 19: 227-44. [CrossRef]

Gangale, Toby. 1984. Still living on the land. In Visitors to Aboriginal Sites: Access, Control and Management: Proceedings of the 1983 Kakadu Workshop. Edited by Hilary Sullivan. Canberra: Australian National Parks and Wildlife Service, p. 57.

Gao, Qian. 2017. Social values and rock art tourism: An ethnographic study of the Huashan rock art area (China). Conservation and Management of Archaeological Sites 19: 82-95. [CrossRef]

George, Tommy. 2013. Fire: And the Story of Burning Country. Text by Cape York Elders and Community Leaders. Photographed and Recorded by Peter McConchie. Avalon: Cyclops Press.

George, Tommy, George Musgrave, and the Ang-Gnarra Rangers. 1995. Our Country, Our Art, Our Quinkans. Laura: Ang-Gnarra Aboriginal Corporation.

Giblin, Angela. 2004. Alligator Rivers Uranium Deposits (Koongarra, Nabarlek and Ranger One) Northern Territory. In Regolith Expression of Australian Ore Systems: A Compilation of Geochemical Case Histories and Conceptual Models. Edited by C. R. M. Butt, M. Cornelius, K. M. Scott and I. D. M. Robertson. Bentley: Cooperative Research Centre for Landscape Environments and Mineral Exploration, pp. 1-4.

Gillespie, David. 1982. The Rock Art and Archaeological Sites of Ubirr, Kakadu National Park NT: The Beginning of a Management Strategy. Kakadu: Australian National Parks and Wildlife Service.

Graetz, Geordan. 2015. Ranger Uranium Mine and the Mirarr (Part 1), 1970-2000: The risks of 'riding roughshod'. The Extractive Industries and Society 2: 132-41. [CrossRef]

Hampson, Jamie. 2015. Presenting rock art and perceiving identity in South Africa and Beyond. Time and Mind 8: 373-91. [CrossRef]

Hartwig, Andrew. 2017. Improving Ground Cover and Resilience on Normanby Station. Cape York Healthy Country Newsletter 32. Available online: http://www.capeyorknrm.com.au/news-events/newsletter/issue32/improving-ground-cover-and-resilience-normanby-station (accessed on 20 August 2019).

Haynes, Christopher D. 2010. Realities, simulacra and the appropriation of Aboriginality in Kakadu's tourism. In Indigenous Participation in Australian Economies: Historical and Anthropological Perspectives. Edited by Ian Keen. Canberra: ANU Press, pp. 165-86.

Hehir, Grant. 2019. Management of Commonwealth National Parks. Auditor-General Report 49 2018-2019. Canberra: Commonwealth of Australia.

Henley, S. G. 2019. Seven Breathtaking Places to Find Aboriginal Rock Art. Available online: https://www.australia. $\mathrm{com} / \mathrm{en} /$ things-to-do/aboriginal-australia/7-breathtaking-places-to-find-aboriginal-rock-art.html (accessed on 27 August 2019).

Hodgson, Renata, Tracey Firth, and Rayka Presbury. 2007. Aboriginal cultural tourism in the Northern Territory: Sociocultural impacts of tourism on the Manyalluk community. In Striving for Sustainability: Case Studies in Indigenous Tourism. Edited by Jeremy Buultjens and Don Fuller. Lismore: Southern University Press, pp. 291-332.

Inspiring Place. 2015. Kakadu National Park Draft Walking Strategy. Unpublished Report Prepared for Parks. Australia. Available online: https://www.environment.gov.au/system/files/resources/dff32921-f83d-4a44bbf3-b295204c739c/files/knp-br-master-130215.rs.pdf (accessed on 2 August 2019).

Katz, Brigit. 2018. India to Cap Number of Taj Mahal Visitors. Smithsonian Magazine. January 4. Available online: https:/www.smithsonianmag.com/smart-news/india-cap-number-taj-mahal-visitors-1-180967738/ (accessed on 5 July 2019).

Kimberley Development Commission. 2019. Tourism. Available online: https://kdc.wa.gov.au/economic-profile/ tourism/ (accessed on 5 July 2019).

Krishna, Ram. 2015. Applied Systems Approach Towards Sustainable Development and Promotion of Protected Rock Art Heritage Sites in India. Ph.D. dissertation, Dyalbargh Educational Institute, Agra, India. Available online: http://shodh.inflibnet.ac.in:8080/jspui/handle/123456789/5700 (accessed on 25 November 2019). 
Little, Terry, and Gloria Kendi Borona. 2014. Can rock art in Africa reduce poverty? Public Archaeology 13: 178-86. [CrossRef]

Logan, William. 2013. Australia, Indigenous peoples and World Heritage from Kakadu to Cape York: State party behaviour under the World Heritage Convention. Journal of Social Archaeology 13: 153-76. [CrossRef]

Marsh, Susan, and Christine Musgrave. 2013. Laura River Dreaming: Country Plan Prepared through Dept of Environment and Resource Management Planning for Country. Available online: https://www.anggnarra. org.au/our-country/laura-rangers (accessed on 5 August 2019).

Marshall, Melissa. 2019. Rock Art Conservation and Management: 21st Century Perspectives from Northern Australia: Kakadu National Park, Western Arnhem Land and the Kimberley. Unpublished Ph.D. thesis, The Australian National University, Canberra, Australia.

Maswood, S. Javed. 2000. Kakadu and the politics of World Heritage Listing. Australian Journal of International Affairs 54: 357-72. [CrossRef]

McDonald, Jo, and Lucia Clayton. 2016. Rock Art Thematic Study; Report to the Department of the Environment and the Australian Heritage Council. Available online: https://www.environment.gov.au/system/files/resources/ 90e93195-385b-4e34-89f9-14d44a189b3b/files/rock-art-thematic-study.pdf (accessed on 25 November 2019).

Morwood, Michael. 2002. Visions from the Past. The Archaeology of Australian Aboriginal Art. Sydney: Allen \& Unwin.

NACCHO. 2019. Aboriginal Health State of Play. Available online: http://www.naccho.org.au/wp-content/ uploads/Key-facts-2-Indigenous-health-at-a-glance-FINAL.pdf (accessed on 12 August 2019).

Neidjie, Bill. 1984. Visitors to sites: A Traditional Owner's perspective. In Visitors to Aboriginal Sites: Access, Control and Management: Proceedings of the 1983 Kakadu Workshop. Edited by Hilary Sullivan. Canberra: Australian National Parks and Wildlife Service, pp. 41-42.

Novelli, Marina. 2004. Niche Tourism: Contemporary Issues, Trends and Cases. Oxford: Elsevier.

O'Faircheallaigh, Ciaran. 2012. International recognition of Indigenous rights, Indigenous control of development and domestic political mobilisation. Australian Journal of Political Science 47: 531-45. [CrossRef]

O'Regan, Tom. 1988. 'Fair dinkum fillums': The Crocodile Dundee phenomenon. Media Information Australia 50: 155-75. [CrossRef]

Palmer, Lisa. 2004. Bushwalking in Kakadu: A study of cultural borderlands. Social and Cultural Geography 5: 109-27. [CrossRef]

Quinkan and Regional Cultural Centre. 2019. Rock Art Sites and Tours. Available online: https://www.quinkancc. com.au/rock-art-sites-tours (accessed on 12 July 2019).

Richards, Greg. 2018. Cultural tourism: A review of recent research and trends. Journal of Hospitality and Tourism Management 36: 12-21. [CrossRef]

Riley, Roger W., and Carlton S. Van Doren. 1992. Movies as tourism promotion: A 'pull' factor in a 'push' location. Tourism Management 13: 267-74. [CrossRef]

Skitmore, Stephen, Iain G. Johnston, and Sally K. May. 2015. Mirarr Gunwarddebim Djidbidjidbi (Mount Brockman) Rock Art Survey and Walking Route Recommendations. Unpublished report prepared for Gundjeihmi Aboriginal Corporation.

Smiechen, Joc, and Alicia Boyle. 2007. Aboriginal tourism research in Australia. In Tourism and Indigenous Peoples: Issues and Implications. Edited by Richard Butler and Tom Hinch. Amsterdam: Elsevier, pp. 58-70.

Smyth, Dermot. 2001. Joint management of National Parks. In Working on Country: Contemporary Indigenous Management of Australia's Lands and Coastal Regions. Edited by Richard Baker, Jocelyn Davies and Elspeth Young. South Melbourne: Oxford University Press, pp. 75-91.

Sullivan, Kate. 1992. Managing the art and archaeological resources of an area near Laura, north Queensland, inscribed as part of the National Estate. Unpublished report prepared for the Ang-Gnarra Aboriginal Corporation and the Queensland Dept of Environment and Cultural Heritage.

Sutherland, Stewart, and Michael Adams. 2019. Building on the definition of social and emotional wellbeing: An Indigenous (Australian, Canadian, and New Zealand) viewpoint. ab-Original 3: 48-72. [CrossRef]

Taçon, Paul. 2001. 'Australia'. In Handbook of Rock Art Research. Edited by David Whitley. Walnut Creek: Rowman and Littlefield, pp. 530-75.

Tonnaer, Anke. 2010. A ritual of meeting: 'Sharing culture' as a shared culture in Australian Indigenous tourism. La Ricerca Folklorica 61: 21-31.

Tourism NT. 2018. Regional Profiles. Kakadu and Arnhem Land Regional Report Three Year Average 2016-2018. Darwin: Tourism NT. 
Trezise, Percy. 1973. Last Days of a Wilderness. Sydney: Collins.

Trost, Margaret. 1979. A world gathering at Cairns: The Second World Wilderness Congress. Geo 2: 7-21.

Ucko, Peter. 1983. The politics of the Indigenous minority. Journal of Biosocial Science 8: 25-40. [CrossRef]

UNESCO World Heritage Centre. 2019. Kakadu National Park. Available online: https://whc.unesco.org/en/list/147/ (accessed on 25 August 2019).

Walsh, Graeme. 1991. Flinders Group National Park site management: Regional resource evaluation, preservation and selective presentation in Far North Queensland. In Rock Art and Posterity: Conserving, Managing and Recording Rock Art. Occasional AURA Publication no. 5. Edited by Colin Pearson and Benjamin Swartz. Melbourne: Australian Rock Art Research Association, pp. 34-44.

Wearing, Stephen, and Monique Huyskens. 2001. Moving on from joint management policy regimes in Australian national parks. Current Issues in Tourism 4: 182-209. [CrossRef]

Wellings, Peter. 1995. Management considerations. In Kakadu: Natural and Cultural Heritage Management. Edited by Tony Press, David Lea, Ann Webb and Graham Alister. Darwin: Australian Nature Conservation Agency, pp. 238-70.

Wellings, Peter. 2007. Joint management: Aboriginal involvement in tourism in the Kakadu World Heritage Area. In Tourism and Protected Areas: Benefits beyond Boundaries. Edited by Robyn Bushell and Paul F. J. Eagles. Wallingford: CAB International, pp. 89-100.

Whitford, Michelle, and Lisa Ruhanen. 2009. Indigenous Tourism Businesses in Queensland: Criteria for Success. An Australian Case Study towards the Development of a National Diagnostic Tool for Indigenous Tourism Businesses. Gold Coast: CRC for Sustainable Tourism.

Whitford, Michelle, and Lisa Ruhanen. 2016. Indigenous tourism research, past and present: Where to from here? Journal of Sustainable Tourism 24: 1080-99. [CrossRef]

Whitford, Michelle, and Lisa Ruhanen. 2017. Indigenous tourism in Australia: History, trends and future directions. In Indigenous Tourism: Case Studies from Australia and New Zealand. Edited by Michelle Whitford, Lisa Ruhanen and Anna Carr. Oxford: Goodfellowe Publishers, pp. 9-24.

Woodward, Albert E. 1973. Aboriginal Land Rights Commission First Report July 1973; Parliamentary Paper 138 of 1973. Canberra: Australian Government Publishing Service.

Woodward, Albert E. 1974. Aboriginal Land Rights Commission Second Report April 1974; Parliamentary Paper 69 of 1974. Canberra: Australian Government Publishing Service.

World Tourism Organisation. 2018. Tourism and Culture Synergies. Madrid: UNWTO.

Yap, Mandy, and Eunice Yu. 2016. Operationalising the capability approach: Developing culturally relevant indicators of Indigenous wellbeing-An Australian example. Oxford Development Studies 44: 315-31. [CrossRef]

(C) 2019 by the authors. Licensee MDPI, Basel, Switzerland. This article is an open access article distributed under the terms and conditions of the Creative Commons Attribution (CC BY) license (http://creativecommons.org/licenses/by/4.0/). 